NBER WORKING PAPER SERIES

\title{
BORROWING CONSTRAINTS AND CONSUMPTION BEHAVIOR IN JAPAN
}

\author{
Midori Wakabayashi \\ Charles Yuji Horioka \\ Working Paper 11560 \\ http://www.nber.org/papers/w11560
}

\author{
NATIONAL BUREAU OF ECONOMIC RESEARCH \\ 1050 Massachusetts Avenue \\ Cambridge, MA 02138 \\ August 2005
}

We would like to thank Daiji Kawaguchi, Yuji Kojima, Colin McKenzie, Yasuyuki Sawada, Shizuka Sekita, Wako Watanabe, Junmin Wan, the members of Horioka's graduate seminar, and seminar participants at Keio University, the Central Council for Financial Services Information, and the Japanese Economic Association meeting of June 2005 for their helpful comments and discussions. This paper was prepared under the supervision of Wataru Suzuki, Associate Professor, Tokyo Gakugei University. We are grateful to the Central Council for Financial Services Information for making these data available to us, and we are especially grateful to Yayoi Abe of the Central Council for Financial Services Information. The views expressed herein are those of the author(s) and do not necessarily reflect the views of the National Bureau of Economic Research.

(C2005 by Midori Wakabayashi and Charles Yuji Horioka. All rights reserved. Short sections of text, not to exceed two paragraphs, may be quoted without explicit permission provided that full credit, including (C) notice, is given to the source. 
Borrowing Constraints and Consumption Behavior in Japan

Midori Wakabayashi and Charles Yuji Horioka

NBER Working Paper No. 11560

August 2005

JEL No. D12, D91, E21, O16

\section{$\underline{\text { ABSTRACT }}$}

In this paper, we use Japanese micro data to examine what characteristics borrowing-constrained households have and whether borrowing constraints have an important influence on household consumption behavior. We identify borrowing-constrained households using three different indicators, some of which are unique to our data source, and find that the characteristics of households that are likely to be borrowing-constrained differ depending on which of the three indicators we use. We also find that changes in current income have a positive and significant impact on changes in consumption in the case of households that are likely to be borrowing-constrained but not in the case of households that are unlikely to be borrowing-constrained. This result suggests that borrowing constraints have an important influence on household consumption behavior and that the presence of borrowing constraints is one explanation for why the life cycle-permanent income hypothesis does not hold in the real world.

Midori Wakabayashi

College of Economics

Osaka Prefecture University

1-1, Gakuen-cho

Sakai, Osaka 599-8531

JAPAN

mwaka@eco.osakafu-u.ac.jp
Charles Yuji Horioka

Institute of Social and Economic Research Osaka University

6-1, Mihogaoka

Ibaraki, Osaka 567-0047

JAPAN

and NBER

horioka@iser.osaka-u.ac.jp 


\section{Introduction}

According to the life cycle-permanent income hypothesis, an individual's consumption depends on her expectations concerning her permanent income rather than on her current income, and thus changes in the individual's consumption from one period to the next should not depend on changes in her current income. However, many empirical studies find that changes in an individual's current income do have a significant impact on changes in her consumption, contrary to the life cycle-permanent hypothesis, and thus the validity of this hypothesis is now in doubt.

One of the most important assumptions of the life cycle-permanent income hypothesis is the assumption of perfect capital markets--that is, that individuals can borrow freely at the current interest rate. When capital markets are imperfect (for example, when the borrowing rate is higher than the deposit rate or when the credit limit of individuals is low), individuals will not be able to borrow freely, and changes in an individual's current income may have a significant impact on changes in her consumption. Thus, whether capital markets are perfect or imperfect drastically alters theoretical predictions concerning individuals' consumption behavior, and it is very important to determine whether or not the assumption of perfect capital markets is valid.

In this paper, we examine what characteristics borrowing-constrained households have and whether borrowing constraints have an important influence on household consumption behavior using Japanese micro data from the 1994 "Public Opinion Survey on Household Savings and Consumption (POSSC) (in Japanese, Chochiku to Shouhi ni kansuru Yoron Chousa)" which was conducted by the Central Council for Savings Information (currently called the Central Council for Financial Services Information). We identify borrowing constrained households using three indicators, some of which are unique to our data source.

The contributions of this paper are as follows: first, some of the indicators we use in our analysis to identify borrowing-constrained households are unique. Previous studies identify 
borrowing-constrained households according to whether or not households possess credit cards (Shintani (1994) and Jappelli et al. (1998)) or whether or not households' non-housing wealth is less than two months' worth of income (Zeldes (1989) and Kohara and Horioka $(1998,2001)$ ). We use these same indicators but we also use information on whether or not households have complaints about the loan screening procedures of financial institutions to identify borrowing-constrained households. In particular, we define borrowing-constrained households as households that want financial institutions to expand their low-interest personal loans and households that want financial institutions to show flexibility when screening loan applications and to take account of applicants' credentials and projects even though their collateral is limited. The former are likely to have abandoned their plans to borrow because the interest rate was too high, and the latter are likely to have had their loan applications turned down due to the lack of collateral, and thus both types of households are likely to be borrowing-constrained. The inclusion of a question about the reasons for consumer dissatisfaction with the loan screening procedures of financial institutions in household surveys is unique, and our use of this question to identify borrowing constrained households is also unique.

Second, the data source we use in our analysis contains various information on loans--for example, new loans per year (flow data), loan repayments per year (flow data), and the total amount of outstanding loans (stock data). In particular, information is available on outstanding loans from each type of borrower--not only from financial institutions but also from money lender companies (consumer credit companies (in Japanese, sarakin) and pawnshops), one's employer, and relatives and acquaintances. Thus, the data source we use in our analysis is well-suited for an analysis of borrowing constraints. .

To preview our main findings, our results show that the characteristics of borrowing-constrained households differ greatly depending on which indicator we use and that 
whether or not households have complaints about the loan screening procedures of financial institutions and whether or not households' non-housing wealth is less than two months' worth of income appear to be far better indicators than whether or not households are using credit cards. We also find that changes in the current income of households that are likely to be borrowing-constrained have a positive and significant impact on changes in their consumption in almost all cases, whereas changes in the income of households that are unlikely to be borrowing-constrained do not have a significant impact on changes in their consumption in any case. These results suggest that borrowing constraints have an important influence on household consumption behavior and that the presence of borrowing constraints is one explanation for why the life cycle-permanent income hypothesis does not hold in the real world.

This paper is organized as follows: In Section 2, we conduct a theoretical analysis of borrowing constraints and their impact on consumption behavior and survey previous studies, in Section 3, we describe the data source and variable definitions, in Section 4, we present some descriptive statistics and cross tabulations, in Section 5, we describe the estimation model and estimation method, in Section 6, we present our estimation results, and Section 7 concludes.

\section{Theoretical Considerations and Previous Research}

\subsection{Theoretical Considerations}

In this subsection, we conduct a theoretical analysis of borrowing constraints and show why an individual's consumption behavior will differ depending on whether or not she is borrowing-constrained using a two-period model (this exposition is based on Ogawa and Horioka $(1996)){ }^{1}$

\footnotetext{
${ }^{1}$ In this theoretical model, we assume for the sake of simplicity that the individual will borrow only when she has no saving. This is an extreme assumption, and as a matter of fact, the proportion of individuals who have some loans but no savings is only $4.88 \%$ (206 out of 4225 observations).
} 
Look at Figure 1. $C_{t}$ is the income of the individual at time $t(t=1,2), y_{t}$ is the income of the individual at time $t(t=1,2)$, and $r$ is the interest rate. We assume that the individual does not hold any assets at the beginning of the first period. First, if the borrowing rate is the same as the deposit rate, and if the individual can borrow freely at the current interest rate, then the individual's budget constraint is the straight line $\mathrm{AD}\left(C_{1}+\frac{C_{2}}{1+r}=y_{1}+\frac{y_{2}}{1+r}\right)$, and the individual chooses the point $\mathrm{E}\left(C_{1}{ }^{*}, C_{2}{ }^{*}\right)$, where an indifference curve is tangent to the budget constraint. In this case, the individual borrows $\left(C_{l}-y_{l}\right)$ because the consumption level in the first period is higher than the income level in the first period.

Next, let us consider the case in which the borrowing rate is higher than the deposit rate, which is a type of borrowing constraint. In this case, the budget constraint of the individual is represented by the kinked line AFD (kink at F): to the left of $C_{l}=y_{l}$, the budget constraint is the line segment AF $\left(C_{1}+\frac{C_{2}}{1+r}=y_{1}+\frac{y_{2}}{1+r}\right)$, whereas to the right of $C_{l}=y_{1}$, the budget constraint is the line segment $\mathrm{FB}\left(C_{1}+\frac{C_{2}}{1+r_{1}}=y_{1}+\frac{y_{2}}{1+r_{1}}\right)$. The individual maximizes her utility subject to this budget constraint. ${ }^{2}$ As Figure 1 is drawn, the individual attains maximum utility $\left(\mathrm{U}_{2}\right)$ at $\mathrm{F}$ $\left(y_{1}, y_{2}\right)$ (the kink point). In this case, the individual consumes all of her income in each period, and thus the individual's saving is zero. Thus, the presence of a borrowing constraint characterized by a borrowing rate that exceeds the deposit rate lowers the utility level of the individual from $U_{1}$ to $U_{2}$.

Consider the case in which the individual's income in period 1 increases from $\mathrm{y}_{1}$ to $\mathrm{y}_{11}$. The budget line of an individual who is not borrowing-constrained shifts from the line AD to the line $\mathrm{GH}$, whereas that of an individual who is borrowing-constrained shifts from the kinked line

\footnotetext{
${ }^{2}$ This same figure can be used to analyze the case in which the individual cannot borrow at all. In this case, the budget line will also be kinked at point $\mathrm{K}$, but the segment $\mathrm{FB}$ will be vertical.
} 
AFB to the kinked line GKI. The former attains maximum utility $\left(\mathrm{U}_{3}\right)$ at $\mathrm{J}\left(\mathrm{C}_{11}, \mathrm{C}_{21}\right)$, whereas the latter attains maximum utility $\left(\mathrm{U}_{4}\right)$ at $\mathrm{K}\left(\mathrm{y}_{11}, \mathrm{y}_{2}\right)$. K indicates that the consumption level of the individual who is borrowing constrained is $\mathrm{y}_{11}$, which implies, as before, that she consumes all of her income in each period and thus that she increases her first-period consumption by the full amount of the increase in her first-period income. Thus, changes in the individual's consumption do not coincide with changes in her income in the former case (unconstrained individuals) whereas they do coincide with changes in her income in the latter case (borrowing-constrained individuals). ${ }^{3}$

\section{2 Previous Research}

In this subsection, we survey the previous literature on the relationship between borrowing constraints and household consumption. A large number of detailed studies have been conducted on this topic using data for countries other than Japan (for example, Hayashi (1985), Zeldes (1989), Jappelli (1990), Runkle (1991), Jappelli, et al. (1998), and Kang and Sawada (2005); see Hayashi (1987) for a survey).

In one of the most seminal studies of whether borrowing constraints are present, Zeldes (1989) tests the permanent income hypothesis against the alternative hypothesis that consumers optimize subject to a well-specified sequence of liquidity constraints using data from the Panel Study of Income Dynamics (PSID). He splits the sample into two groups on the basis of the ratio of non-housing wealth to income on the grounds that observations with low ratios are likely to be borrowing-constrained, whereas those with high ratios are unlikely to be borrowing-constrained. He finds that the results are generally, but not completely, supportive of

\footnotetext{
${ }^{3}$ If the magnitude of the increase in income is large, the budget constraint might shift from the kinked line AFD to the straight line GH (rather than the kinked line GKI). In this case, the individual becomes unconstrained.
} 
the view that liquidity constraints have an important influence on people's consumption. However, as Jappelli (1990) points out, the main limitation of Zeldes (1989) and other previous studies is that borrowing-constrained consumers are not observable directly and have to be identified via indirect evidence--for example, on the basis of the ratio of non-housing wealth to income. By contrast, the 1983 Survey of Consumer Finances (SCF), which Jappelli (1990) uses in his analysis, provides direct information on borrowing constraints (i.e., information on whether households' requests for credit have been rejected by financial intermediaries), and thus these data can be used to analyze the impact of credit market imperfections and personal characteristics on borrowing constraints. Jappelli (1990) finds that about 19.0 percent of households are rationed in the credit market and also finds that younger families with low levels of wealth and saving are more likely to be borrowing-constrained. Jappelli (1990) cannot analyze the relationship between borrowing constraints and household consumption behavior because the SCF does not collect information on people's consumption, but Jappelli et al. (1998) link the SCF and PSID data and test for the presence of borrowing constraints using the following two-step procedure: first, they use the direct information on borrowing constraints from the SCF to analyze the determinants of the probability of being borrowing-constrained. Second, they estimate a switching regression model of the Euler equation combining data from the SCF and PSID and using a two-sample instrumental-variables technique. They find that the excess sensitivity of consumption associated with the possibility of being borrowing-constrained is stronger in the case of their methodology than in the case of the sample splitting approach. Kang and Sawada (2005) examine how the credit crunch in Korea affected households' welfare in 1997 and 1998 using a switching regression approach and data from the Korean Household Panel Survey and find that the standard consumption Euler equation, a necessary condition of the life-cycle permanent income hypothesis, does not hold because of binding credit constraints. 
Many studies have been conducted of whether the presence of borrowing constraints affects household consumption in Japan as well (for example, Ogawa (1990), Shintani (1994), Kohara and Horioka (1998, 2001), and Sawada et al. (2004)), but most of these studies analyze the relationship between borrowing constraints and the level of consumption rather than the change therein. For example, Shintani (1994) analyzes whether the presence of borrowing constraints affects household consumption using the 1989 and 1990 data from the "Nikkei-Needs RADAR Survey on Financial Behavior (RADAR)," conducted by the Data Bank Bureau of Nihon Keizai Shimbun, Inc., and finds that a significant fraction of households are borrowing-constrained and that, if borrowing constraints were to be lifted, aggregate consumption would increase 7\% in 1989 and 5\% in 1990. Kohara and Horioka (1998) use 1993-97 data from the "Japanese Panel Survey of Consumers (JPSC)," conducted by the Institute for Household Economy, which collects direct information on borrowing constraints (the same question as in the SCF) and find that eight percent of households are borrowing-constrained. They also estimate the consumption function of borrowing-constrained households using a sample selection model and find that the income of borrowing-constrained households has little impact on their consumption. Kohara and Horioka (2001) and Sawada et al. (2004) are the only studies that analyze the relationship between borrowing constraints and changes in the household's consumption. Kohara and Horioka (2001) analyze data from the JPSC and find that eight percent of households are borrowing-constrained and that borrowing constraints do not explain why the Euler equation does not hold. Sawada et al. (2004) estimate the augmented Euler equation using data from the JPSC and Amemiya's (1985) Type 5 Tobit model and find that their results reject the standard consumption Euler equation, a necessary condition of the life-cycle permanent income hypothesis. They also find using data for the 1993-99 period that the credit crunch became especially serious after 1997. 


\section{Data}

\subsection{The Data Source}

In this subsection, we describe the data source we use in our analysis. We use micro data from the 1994 "Public Opinion Survey on Household Savings and Consumption (POSSC) (in Japanese, Chochiku to Shouhi ni kansuru Yoron Chousa)" which was conducted by the Central Council for Savings Information (currently called the Central Council for Financial Services Information). This survey has been conducted once a year since 1953 and collects various information on respondents' behavior--for example, their income, consumption, saving, portfolio choice, lifetime planning, the extent of their knowledge about the financial environment, etc. In the 1994 survey, a stratified two-stage random sample of 6,000 households with at least two members was surveyed using the drop-off, pick-up method, resulting in 4,225 responses (a response rate of $70.4 \%)$.

There are at least three advantages to using these data in our analysis. First, we can use three indicators to identify borrowing-constrained households, some of which are unique to our data source (see the introduction for more details). Second, this survey collects information not only on the levels of various variables (for example, living expenses, saving, and annual income) but also on the change therein. Thus, we can use the data from this survey as panel data even though the survey is a cross section survey. Third, the data we use in our analysis contains various information on loans--for example, new loans per year, loan repayments per year (flow data), and the total amount of outstanding loans (stock data). In particular, information is available on outstanding loans from each type of borrower (government housing loan financial institutions, other financial institutions (banks, cooperative banks (in Japanese, Shinkin and Shinkumi), industrial banks, agricultural and fishery banks, post offices, insurance companies, and 
housing loan financial institutions), sales companies and credit card companies, money lender companies (consumer credit companies (in Japanese, Sarakin) and pawnshops), employers, and relatives and acquaintances, six types of borrowers in total) and on outstanding loans by borrowing motive (housing loans, unspecified loans (in Japanese, free loans), and educational loans, three motives in total). We use data from the 1994 survey because it is the most recent survey to collect information on the usage of credit cards, which is needed for one of the methods we use to identify borrowing-constrained households. We dropped all observations for which all of the necessary information is not available, which reduced the number of observations from 4,225 to 1,777 .

3.2 Three indicators for the presence of borrowing constraints

The POSSC collects information on three indicators that can be used to identify borrowing-constrained households, and in this subsection we discuss these indicators. One question the POSSC asks is the following:

1. What complaints the respondent has about the loan screening procedures of financial institutions

Question: Do you have any complaints about the services of financial institutions, or do you desire any improvements in these institutions?

There are 13 responses to this question and two of them can be used to identify borrowing-constrained households:

(a) Financial institutions should expand their low-interest personal loans.

(b) Financial institutions should show flexibility when screening loan applications and take account of applicants' credentials and projects even though their collateral is limited. 
With respect to response (a), if financial institutions offered lower interest rates, respondents would presumably have taken out loans from these institutions, and they have presumably abandoned their plans to borrow because interest rates were too high. Thus, we can say that respondents choosing response (a) are likely to be borrowing-constrained. With respect to response (b), respondents have presumably had their loan applications turned down due to the lack of collateral,.and if financial institutions had not turned down their loan applications, they would presumably have taken out loans from these institutions. Thus, we can say that respondents choosing response (b) are likely to be borrowing-constrained. In our analysis, we assume that respondents are likely to be borrowing-constrained if they picked one or both of these responses. $^{4}$

(2) Whether or not the respondent uses credit cards

Jappelli et al. (1998) classify as borrowing-constrained households that have neither a credit card nor a credit line. They explain that even households whose loan applications were turned down may not be truly constrained because they can borrow at least some amount if they possess credit cards. The survey we use in our analysis asks whether or not households are using credit cards, so we use this information as a second indicator in our analysis.

When individuals apply for credit cards, credit card companies request extensive information on applicants' occupations, incomes, loans, etc., in order to determine whether or not to grant the individual a credit card and in order to determine the individual's credit limit. Individual can be regarded as being borrowing-constrained if their credit card applications were denied or if the credit limit is too low.

The POSSC asks the following question relating to the use of credit cards:

${ }^{4}$ The proportion of respondents who chose response (a) is $19 \%$, the proportion who chose response (b) is $13 \%$, and the proportion who chose both responses is $4.5 \%$. 
Question: Is your household using credit cards?

(a) Yes, we are using credit cards.

(b) No, we are not using credit cards.

In our analysis, we assume that respondents are likely to be borrowing-constrained if they choose response (b). ${ }^{5}$

(3) Zeldes' (1989) indicator -- the ratio of non-housing wealth to monthly income

Zeldes (1989) splits his sample into two groups on the basis of the ratio of wealth to monthly income. In particular, in method (i), he assumes that households whose estimated non-housing wealth is less than two months' worth of income are likely to be borrowing-constrained, whereas all other households are unlikely to be borrowing-constrained; in method (ii), he assumes that households whose saving is zero or whose estimated non-housing wealth is zero are likely to be borrowing-constrained, whereas those whose estimated non-housing wealth is at least six months' worth of income are unlikely to be borrowing-constrained; and in method (iii), he assumes that households whose estimated total wealth (including housing equity) is less than two months' worth of income are likely to be borrowing-constrained, whereas all other households are unlikely to be borrowing-constrained. Since Zeldes seems to favor method (i) and devotes most of his discussion to it, we also use this indicator. Our detailed calculation method is as follows: first, we calculate non-housing wealth as the sum of bank deposits and postal savings, financial trusts, loan trusts, equities, bonds, investment trusts, property formation saving, and other financial products (not including life insurance, individual pensions, and accident insurance). Second, since there is no information on the amount of monthly income in the survey we use, we calculate monthly income by dividing

\footnotetext{
${ }^{5}$ In the survey from which this question is taken, households that have credit cards but do not use them answer (b) to this question.
} 
yearly income by $12 .^{6}$

\section{Descriptive Statistics}

\subsection{Descriptive Statistics}

In this subsection, we present the main descriptive statistics for all households and for households that are likely to be borrowing-constrained. We discuss our results for each of the three indicators we use to identify borrowing-constrained households (see the introduction and section 3).

First, we compare the descriptive statistics for the subsample of households that have complaints about the loan screening procedures of financial institutions (hereafter abbreviated as "households that have complaints") (the first indicator) with those for all households. The proportion of respondents who have complaints is $27.7 \%$ (493/1777), and two interesting patterns emerge: first, the average age of the household head is 46.8 in the case of households that have complaints, which is about three years younger than that of all households. Second, households that have complaints have more loans than all households. For example, in the case of households that have complaints, the proportion of households that have loans outstanding is $60.2 \%$, which is about 16 percentage points higher than in the case of all households. Moreover, the average amount of new loans per year is about 540,000 yen in the case of households that

\footnotetext{
${ }^{6}$ We also tried other indicators that are combinations of these three indicators (for example, (a) households that have complaints about the loan screening procedures of financial institutions and are not using credit cards (13.5\% (239 out of 1777 observations)), or (b) households that have complaints and households whose non-housing wealth is less than two months' worth of income (6.5\% (116 out of 1777 observations)), etc. We do not present the results here because the characteristics of households that are likely to be borrowing-constrained differ depending on which of the three indicators we use (in particular, the characteristics of non-credit card users are very different from those of households who are likely to be borrowing-constrained according to the other two criteria) (see sections 4 and 5 for details). For example, the characteristics of households that are likely to be borrowing-constrained according to indicator (b) are similar to those of households that have complaints, whereas those of households that are borrowing-constrained according to indicator (a) escape characterization..
} 
have complaints, which is about 200,000 yen $(60 \%)$ higher than in the case of all households; the average amount of loan repayments per year is 710,000 yen in the case of households that have complaints, which is about 200,000 yen $(39 \%)$ higher than in the case of all households; and the total amount of outstanding loans is 6.4 million yen in the case of households that have complaints, which is about 2.1 million yen (50\%) higher than in the case of all households. Furthermore, the average amounts of loans from each type of borrower are almost always higher in the case of households that have complaints than in the case of all households (except in the case of loans from relatives and acquaintances). A closer look at the results by type of borrower show that the average amount of loans from government housing loan financial institutions hardly differs at all according to whether or not households have complaints, whereas the average amounts of loans from sales companies and credit card companies and money lender companies are much higher in the case of households that have complaints than in the case of all households: for example, the average amount of loans from sales companies and credit card companies is two times higher and the average amount of loans from money lender companies is three times higher in the case of households that have complaints than in the case of all households. These findings suggest that households that have complaints have more loans, especially unspecified loans, than all households, suggesting that these households have complaints about the loan screening procedures of financial institutions because they already have considerable outstanding loans and hence are unable to borrow more from financial intermediaries.

Second, we compare the descriptive statistics for households that are not using credit cards (hereafter referred to as "non-credit card users") (the second indicator) with those for all households. The proportion of non-credit card users is $57.8 \%(1027 / 1777)$, and the characteristics of non-credit card users are very different from those of households that have complaints. First, non-credit card users have fewer loans than all households, whereas 
households that have complaints have more loans than all households. For example, in the case of non-credit card users, the proportion of households that have loans outstanding is $37 \%$, the average amount of new loans per year is about 310,000 yen, and the average amount of loan repayments per year is about 410,000 yen, and all of these amounts are much lower than both the case of households that have complaints and the case of all households. On the other hand, the average amount of loans from relatives and acquaintances is 20,000 yen $(31 \%)$ higher in the case of households that are not using credit cards than in the case of all households, which suggests the possibility that these households have no other choice but to borrow money from relatives and acquaintances because they are unable to borrow from financial institutions.

Finally, I compare the descriptive statistics of households whose non-housing wealth is less than two months' worth of income (hereafter abbreviated as "low-ratio households") with those of all households. ${ }^{7}$ The proportion of low-ratio households is $15 \%(267 / 1777)$, suggesting that these households are much fewer in Japan compared to the U.S. ${ }^{8}$ The average yearly income of low-ratio households is 5.8 million yen, which is almost the same as that of all households, whereas the average non-housing wealth of low-ratio households is 0.34 million yen, which is far lower than in the case of all households. The characteristics of low-ratio households are similar to those of households that have complaints. For example, in the case of low-ratio households, the average amount of new loans per year is about 690,000 yen, the average amount of loan repayments per year is about 760,000 yen, and the total amount of outstanding loans is about 6.7 million yen, and all of these amounts are the highest of any category. In addition,

\footnotetext{
${ }^{7}$ We also tried dividing the sample according to whether or not households' non-housing wealth is less than three, four, and six months' worth of income because households' non-housing wealth is much higher in Japan than it is in the U.S., but we do not present the results here because they were not significantly different from the results based on two months' worth of income. The proportion of households whose non-housing wealth is less than three, four, and six months' worth of income is $20.3 \%$ (361/1777), 26.2\% (467/1777), and 36.2\% (644/1777), respectively.

${ }^{8}$ Zeldes (1989) finds that the proportion of low-ratio households is $67 \%$ using data from the PSID, and Jappelli et al. (1998) find that the proportion thereof is $62.1 \%$ using data from the SCF.
} 
loans from sales companies and credit card companies and loans from money lender companies are much higher in the case of low-ratio households than in the case of all households.

Thus, we find that the characteristics of households that are likely to be borrowing-constrained differ depending on which of the three indicators we use.

4.2 The relationship between consumption changes and income changes--discussion using cross-tabulations

In this subsection, we discuss the relationship between consumption changes and income changes using cross-tabulations from the data source we use in our analysis. As we discussed in the introduction and section 3 , the data source we use in our analysis collects information on changes in a household's income and consumption even though the survey is a cross-section survey. The survey asks for disposable household income (after-tax household income) in the previous year and in the year before that, whereas the question about the change in a household's consumption is as follows:

Question: Did you change your consumption expenditure last year compared to the year before last?

The answers are as follows:

(a) We increased our consumption expenditure.

(b) We did not change our consumption expenditure.

(c) We reduced our consumption expenditure.

We divide the sample into the following four groups using these questions: (1) the case in which there were changes in both income and consumption and the direction of the change therein was the same: we consider households in this group to be more likely to be borrowing-constrained; (2) the case in which there is a change in the household's income but no 
change in its consumption: in this case, changes in the household's consumption do not depend on changes in its current income, and thus households in this group are behaving in accordance with the life cycle-permanent income hypothesis $(\mathrm{LC} / \mathrm{PIH})$ : (3) the case in which there is no change in either consumption or income: households in this group might either be borrowing-constrained or behave in accordance with the LC/PIH; (4) all other cases--for example, the case in which there are changes in both income and consumption but the direction of the changes therein is opposite: households in this group are behaving irrationally.

As can be seen from Table 2-1, the proportion of those in the first group is $26.79 \%$ $(4.90 \%+21.89 \%)$, that of those in the second group is $24.87 \%(7.37 \%+17.50 \%)$, that of those in the third group is $17.56 \%$, and that of those in the fourth group is $30.79 \%$ $(4.56 \%+4.73 \%+7.43 \%+14.07 \%)$.

Let us look first at households that have complaints (Table 2-2). $40.5 \%$ of these households are in the first group, and this figure is 13.7 percentage points higher than in the case of all households, whereas $22.9 \%$ of households that have complaints are in the second group, which is 2.0 percentage points lower than in the case of all households, suggesting that households that have complaints are more likely to be borrowing-constrained and less likely to be behaving in accordance with the LC/PIH. This suggests that this indicator might be appropriate.

Let us look next at non-credit card users (Table 2-3). $\quad 24.7 \%$ of these households are in the first group, and $25.3 \%$ are in the second group. These figures are roughly the same as the figures for all households, which suggest that this indicator is not a very appropriate one.

Lastly, let us look at households whose non-housing wealth is less than two months' worth of income (Table 2-4). $31.5 \%$ of these households are in the first group is, which is 4.7 percentage points higher than in the case of all households, whereas $15.0 \%$ are in the second group, which is 9.9 percentage points lower than in the case of all households. Thus, the 
relationship between consumption changes and income changes of low-ratio households is similar to that of households that have complaints, suggesting that this indicator might also be appropriate.

Thus, we find using cross-tabluations that at least two of three indicators appear to be appropriate. We conduct a more rigorous econometric analysis in the next section.

\section{The Estimation Model}

In this section, we discuss the estimation model we used in our analysis

5.1 What characteristics do borrowing-constrained households have?

We use the following estimation model to test what characteristics borrowing-constrained households have.

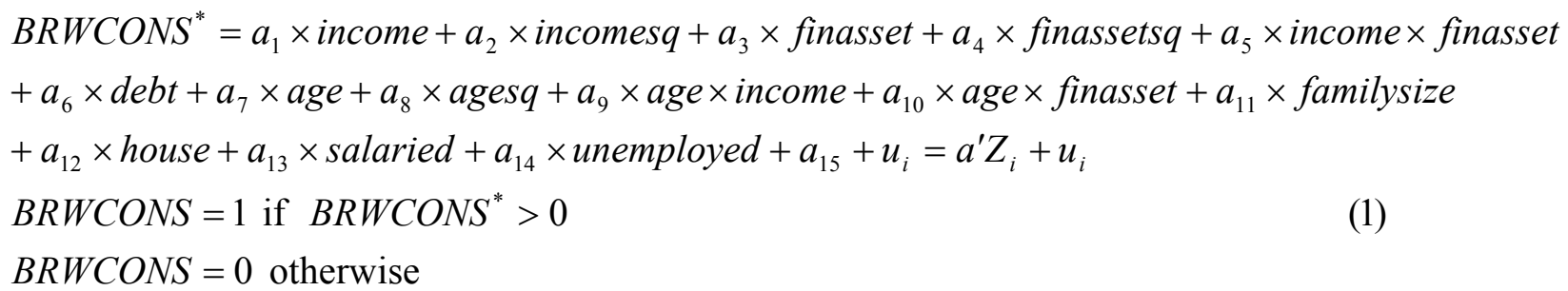

The dependent variable (BRWCONS) is a dummy variable that equals one for households that are likely to be borrowing-constrained. We use the aforementioned three indicators to determine whether a household is likely to be borroing-constrained (see the introduction and section 3). The explanatory variables are household disposable income (income), its square (incomesq), non-housing wealth (finasset), its square (finassetsq), the cross-product of income and non-housing wealth (income*finasset), a dummy variable for whether or not the household owns its own home (house), three sets of variables that are related to outstanding loans ((a) the 
total amount of outstanding loans, (b) outstanding loans from each type of borrower (six types of borrowers in total) and (c) outstanding loans by borrowing motive (three motives in total)), demographic variables: the household head's age (age), its square (agesq), the cross-product of age and income and that of age and non-housing wealth (age*income and age*finasset), the number of family members (familysize), a dummy variable that equals one for households whose head is a salaried worker and zero for households whose head is a self-employed worker or not working (salaried), and a dummy variable that equals one for households whose head is unemployed and zero for households whose head is working or has already retired (unemployed). ${ }^{9}$

In this analysis, the estimation method we use is probit because the dependent variable BRWCONS is discrete.

5.2 Do borrowing constraints have an important influence on household consumption behavior?

We use the following two equations to test whether the determinants of changes in a household's consumption $(C D I F)$ differ significantly depending on whether or not it is likely to be borrowing-constrained: ${ }^{10}$

Regime 1

$$
\begin{aligned}
C D I F^{*}=b_{11} \times i d i f+ & b_{12} \times \text { age }+b_{13} \times \text { agesq }+b_{14}+u_{1 i} \\
& =b_{1}^{\prime} x_{1 i}+u_{1 i} \quad \text { iff } a^{\prime} Z_{i} \geq-u_{i} \quad(2-1)
\end{aligned}
$$

Regime 2

\footnotetext{
${ }^{9}$ We assumed that those not working and aged 59 or under are unemployed and that those not working and aged 60 or older are retired.

10 We use the conventional approach of estimating log-linearized consumption Euler equations (that is, we regress the change in a household's current income on the change in its consumption) to analyze the relationship between borrowing constraints and consumption behavior even though some authors (e.g., Carroll (2001) and Ludvigson and Paxson (2001)) have cast doubt on the validity of this approach.
} 


$$
\begin{aligned}
\text { DDIF }^{*}=b_{21} \times \text { idif }+ & b_{22} \times \text { age }+b_{23} \times \text { agesq }+b_{24}+u_{2 i} \\
& =b_{2}^{\prime} x_{2 i}+u_{2 i} \quad \text { iff } a^{\prime} Z_{i}<-u_{i} \quad(2-2)
\end{aligned}
$$

$$
\begin{aligned}
& C D I F=0 \text { if } C D I F^{*} \leq 0 \\
& C D I F=1 \text { if } 0<C D I F^{*} \leq \mu \\
& C D I F=2 \text { if } \mu<C D I F^{*}
\end{aligned}
$$

We use equation (1) for the criterion function that determines which of these two equations is applicable:

$$
\begin{aligned}
\text { BRWCONS } & =1 \text { if } a^{\prime} Z_{i} \geq-u_{i} \\
& =0 \text { otherwise }
\end{aligned}
$$

The dependent variable $(C D I F)$ of the model is a three-outcome ordered variable that equals zero for households that reduced their consumption last year compared to the year before last, one for households that did not change their consumption last year compared to the year before last, and two for households that increased their consumption last year compared to the year before last. If households behave in accordance with the life cycle model, changes in the household's consumption from one period to the next should not depend on changes in its current income, so idif $\left(=\ln \left(\frac{\text { income for the last year }}{\text { income for the year before last year }}\right)\right)$ (the rate of change of income from the year before last to last year) should not have any impact on CDIF. If, however, households are borrowing constrained, idif should have a positive and significant effect on CDIF. We also include variables such as household head's age (age) and its square (agesq) to proxy for changes in preferences over the life cycle.

We use an ordered response model with a switching regression assuming that $u_{i}$ is correlated with $u_{1 i}$ and $u_{2 i}$. That is, we estimate $b_{1}, b_{2}$ using the following response probabilities. $^{11}$

${ }_{11} \Phi(h, k, \rho)$ is a joint cumulative bivariate normal distribution of the correlation coefficient $\rho$, cumulated over the interval $(-\infty, h] \times(-\infty, k]$ : 
The conditional probabilities of equation (2-1) are:

$$
\left\{\begin{array}{l}
P(C D I F=0 \mid B R W C O N S=1, Z)=\Phi\left(-b_{1}^{\prime} x_{1}, a^{\prime} Z, \rho\right) \\
P(C D I F=1 \mid B R W C O N S=1, Z) \\
\left.=\Phi\left(-b_{1}^{\prime} x_{1}+\mu_{1}, a^{\prime} Z, \rho\right)\right)-\Phi\left(-b_{1}^{\prime} x_{1}, a^{\prime} Z, \rho\right) \\
P(C D I F=2 \mid B R W C O N S=1, Z)=1-\Phi\left(-b_{1}^{\prime} x_{1}+\mu_{1}, a^{\prime} Z, \rho\right)
\end{array}\right.
$$

Similarly, the conditional probabilities of equation (2-2) are:

$$
\begin{aligned}
& \left\{\begin{array}{l}
P(C D I F=0 \mid B R W C O N S=0, Z)=\Phi\left(-b_{2}^{\prime} x_{2},-a^{\prime} Z, \rho\right) \\
P(C D I F=1 \mid B R W C O N S=0, Z) \\
=\Phi\left(-b_{2}^{\prime} x_{2}+\mu_{2},-a^{\prime} Z, \rho\right)-\Phi\left(-b_{2}^{\prime} x_{2},-a^{\prime} Z, \rho\right) \\
P(C D I F=2 \mid B R W C O N S=0, Z)=1-\Phi\left(-b_{2}^{\prime} x_{2}+\mu_{2},-a^{\prime} Z, \rho\right)
\end{array}\right. \\
& \quad \rho=\operatorname{Corr}\left(u_{i}, u_{i N}\right) \mathrm{N}=1,2
\end{aligned}
$$

and thus the likelihood function for this model is

$$
\left\{\begin{array}{l}
L=\Phi\left(-b_{1}^{\prime} x_{1},-a^{\prime} Z, \rho_{1}\right)^{D_{10}=1}\left[\Phi\left(-b_{2}^{\prime} x_{2}+\mu_{2},-a^{\prime} Z, \rho_{1}\right)-\Phi\left(-b_{2}^{\prime} x_{2},-a^{\prime} Z, \rho_{1}\right)\right]^{D_{11}=1} \\
{\left[1-\Phi\left(-b_{2}^{\prime} x_{2}+\mu_{2},-a^{\prime} Z, \rho_{1}\right)\right]^{D_{12}=1} \Phi\left(-b_{2}^{\prime} x_{2},-a^{\prime} Z, \rho_{2}\right)^{D_{00}=1}} \\
{\left[\Phi\left(-b_{2}^{\prime} x_{2}+\mu_{2},-a^{\prime} Z, \rho_{2}\right)-\Phi\left(-b_{2}^{\prime} x_{2},-a^{\prime} Z, \rho_{2}\right)\right]^{D_{01}=1}\left[1-\Phi\left(-b_{2}^{\prime} x_{2}+\mu_{2},-a^{\prime} Z, \rho_{2}\right)\right]^{D_{02}=1}}
\end{array}\right.
$$$$
\left\{\begin{array}{l}
D_{10}=1 \text { if } B R W C O N S=1 \text { and } C D I F=0 \text { and zero otherwise } \\
D_{11}=1 \text { if } B R W C O N S=1 \text { and } C D I F=1 \text { and zero otherwise } \\
D_{12}=1 \text { if } B R W C O N S=1 \text { and } C D I F=2 \text { and zero otherwise } \\
D_{00}=1 \text { if } B R W C O N S=0 \text { and } C D I F=0 \text { and zero otherwise } \\
D_{01}=1 \text { if } B R W C O N S=0 \text { and } C D I F=1 \text { and zero otherwise } \\
D_{02}=1 \text { if } B R W C O N S=0 \text { and } C D I F=2 \text { and zero otherwise }
\end{array}\right.
$$

\section{Estimation Results}

6.1 What characteristics do borrowing-constrained households have?

In this subsection, we present our estimation results concerning the characteristics of households that are likely to be borrowing-constrained. We discuss our results for each of the

$$
\Phi(h, k, \rho)=\frac{1}{2 \pi \sqrt{1-\rho^{2}}} \int_{-\infty}^{h} \int_{-\infty}^{k} \exp \left\{-\frac{1}{2\left(1-\rho^{2}\right)}\left(x_{1}^{2}-2 \rho x_{1} x_{2}+x_{2}^{2}\right)\right\} d x_{1} d x_{2}
$$


three indicators we use to identify borrowing-constrained (see the introduction and section 3).

Let us look first at the results from estimating equation (1) using the first indicator (Table 3-(1), columns (a), (b), and (c)). First, the coefficient of income (household disposable income) is negative and marginally significant in every case, meaning that the lower a household's disposable income is, the higher is the probability of having loan applications turned down, which is consistent with our expectations. The coefficient of finasset (non-housing wealth) is not significant in any of the three cases, which is contrary to expectation, whereas the coefficient of house (a dummy variable for whether or not the household owns its own home), which is a proxy for real assets, is negative and significant in almost every case, suggesting that the higher a household's wealth is, the lower is its need for loans (the demand factor) and the lower is the probability of having its loan application turned down (the supply factor), which is consistent with our expectations. The coefficient of age (the household head's age) is positive and significant, which is contrary to expectation because borrowing constraints are more important for younger families due to supply side adverse selection. In addition, we use the following three sets of variables that pertain to outstanding loans: (a) the total amount of outstanding loans, (b) outstanding loans from each type of borrower (six types of borrowers in total) and (c) outstanding loans by borrowing motive (three motives in total). We would expect that the higher outstanding loans are, the higher is the probability of having loan applications turned down (the supply factor), and thus we would expect all of the coefficients of variables pertaining to outstanding loans to be positive. Let us look first at the results using (a) the total amount of outstanding loans as an explanatory variable. The coefficient of the total amount of outstanding loans is positive and significant, suggesting that the higher the total amount of outstanding loans is, the more likely it is that the household has complaints about the loan screening procedures of financial institutions. We look next at the results using (b) outstanding loans from each type of borrower as explanatory 
variables. The coefficient of loans from government housing loan financial institutions, loans from other financial institutions, loans from sales companies and credit card companies, and loans from money lender companies have a positive and significant effect on BRWCONS. In addition, the estimated value of the marginal effects of loans from sales companies and credit card companies and that of loans from money lender companies are 0.81 and 4.78 , respectively, meaning that if loans from these institutions increase by 100,000 yen, the probability of being borrowing- constrained increases by $0.8 \%$ and $4.9 \%$, respectively. Looking lastly at the results using (c) outstanding loans by borrowing motive as explanatory variables, we find that not only do all of the borrowing motives have positive and significant effects on BRWCONS but that the effect of the total amount of unspecified loans thereon is much larger than that of the total amount of housing loans.

Looking next at the results from estimating equation (1) using the second indicator (Table 3-(2), columns (a), (b), and (c)), we find that the coefficient of income (household disposable income) is negative and significant, as expected, whereas the coefficient of finasset is positive and significant, contrary to expectation. In addition, although the coefficients of the amount of outstanding loans from financial institutions and from sales companies and credit card companies are negative and significant, contrary to expectation, we would like to focus on the coefficient of loans from relatives and acquaintances, which is positive and significant. This result might reflect the fact that non-credit card users may have abandoned their plans to borrow from sales companies and credit card companies and thus that they might have no other choice but to borrow from relatives and acquaintances.

Finally, we look at the results from estimating equation (1) using the third indicator (Table 3-(3), columns (a), (b), and (c)) and find that the results are similar to the results using the first indicator. For example, almost all of the coefficients of variable pertaining to outstanding 
loans are positive and significant, suggesting that low-ratio households have a higher amount of loans than other households.

Thus, the characteristics of households that are likely to be borrowing-constrained differ depending on which of the three indicators we use. That is, the characteristics of households that have complaints and that of low-ratio households have a higher amount of outstanding loans, especially "unspecific" loans, than all households, whereas non-credit card users have a lower amount of outstanding loans than all households except that they borrow more from relatives and acquaintances.

Finally, our results show that we need to exercise caution when selecting indicators for identifying borrowing-constrained households because some indicators are better than others, with whether or not households are using credit cards being the most problematic. Households that are not using credit cards include not only households whose credit card applications were denied but also those who did not apply for credit cards even though their applications would have been approved and those who own but do not use credit cards because they dislike owning and/or using them. ${ }^{12}$ In addition, elderly households might have a lower probability of not using credit cards than younger households because the former might not be accustomed to using them. This might be the reason why the average age of the household head is 52 years old in the case of non-credit card users, which is the highest age of any category. Similarly, households living in rural areas might have a higher probability of not using credit cards than households living in urban areas because credit cards are less widely accepted in rural areas than in urban areas.

In addition, let us look at Figures 2-1 and 2-2. These figures plot the probability of being borrowing-constrained against current income keeping all other variables constant at their sample

${ }^{12}$ We think that the reason why the POSSC has not asked the question about whether or not households are using credit cards since the 1995 survey is that almost all Japanese had credit cards by then. 
mean values (Jappelli (1990) uses the same method on U.S. data). Looking first at Figure 2-1, which is based on the first indicator (whether or not households have complaints), the probability of being borrowing constrained is a decreasing function of current income, which is consistent with the presence of borrowing constraints (and also consistent with Jappelli's (1990) findings based on U.S. data), whereas in Figure 2-2, which is based on the second indicator (whether or not households are using credit cards), the impact of current income on the probability of being borrowing constrained is not clear, suggesting that whether or not households are using credit cards is more problematic than the other two indicators. The descriptive statistics also support these results.

6.2 Do borrowing constraints have an important influence on household consumption behavior?

In this subsection, we examine whether the determinants of changes in a household's consumption differ significantly depending on whether or not it is likely to be borrowing-constrained.

Table 4, (1-1) and (1-2) presents the results from estimating equations (2)-(1) and (2)-(2) using the first indicator (whether or not households have complaints about the loan screening procedures of financial institutions) in the first step. Looking at the impact of idif (the change in the household's income) on CDIF (the change in the household's consumption), the coefficient of idif is positive and significant at the $10 \%$ level only in the case of households that are likely to be borrowing-constrained and is insignificant in the case of households that are unlikely to be borrowing-constrained. The derivatives of the three probabilities with respect to the change in income are as follows: 


$$
\begin{aligned}
& \frac{\partial P_{0}}{\partial \text { idif }}=-0.196 \times 0.229=-0.045 \\
& \frac{\partial P_{1}}{\partial \text { idif }}=(0.196-0.298) \times 0.229=-0.023 \\
& \frac{\partial P_{2}}{\partial \text { idif }}=0.298 \times 0.229=0.068
\end{aligned}
$$

(evaluated at $-b_{1} \overline{x_{1}}=-1.193, \mu_{1}-b_{1} \overline{x_{1}}=0.765$ ); the predicted probabilities and densities are $\Phi(-1.193)=0.116, \Phi(0.675)=0.778, \phi(-1.193)=0.196, \phi(0.765)=0.298 \quad, \quad$ respectively $)$. This implies that, if the change in the household's income increases by 1 percentage point, the probability of the household decreasing its consumption decreases by 4.5 percentage points, the probability of the household not changing its consumption increases by 2.3 percentage point, and the probability of the household increasing its consumption increases by 6.8 percentage points.

We look next at the results using the second indicator (whether or not households are using credit cards) in the first step and again find that the coefficient of idif is positive and significant only in the case of households that are likely to be borrowing-constrained and is not significant in the case of households that are unlikely to be borrowing-constrained. The derivatives of the three probabilities with respect to the change in income are as follows:

$$
\begin{aligned}
& \frac{\partial P_{0}}{\partial i d i f}=-0.206 \times 0.226=-0.047 \\
& \frac{\partial P_{1}}{\text { Didif }}=(0.206-0.104) \times 0.226=0.023 \\
& \frac{\partial P_{2}}{\partial i d i f}=0.104 \times 0.226=0.024
\end{aligned}
$$

meaning that, for example, if the change in the household's income increases by 1 percentage point, the probability of the household decreasing its consumption decreases by 4.7 percentage points, which is consistent with the presence of borrowing constraints.

Finally, we look at the results using the third indicator (whether or not households' non-housing wealth is less than two months' worth of income) in the first step. We found that 
changes in the household's income do not have any impact on changes in its consumption in the case of households that are unlikely to be borrowing-constrained, as expected, whereas changes in the household's income do not have any impact on changes in its consumption in the case of households that are likely to be borrowing constrained either, which is contrary to expectation.

To summarize our findings in this section, we find evidence that changes in the current income of households that are likely to be borrowing-constrained have a positive and significant impact on changes in their consumption (except in the case of low-ratio households), whereas changes in the income of households that are unlikely to be borrowing-constrained do not have any impact on changes in their consumption, suggesting that borrowing constraints have an important influence on household consumption behavior. ${ }^{13}$

\section{Conclusion}

In this paper, we examined what characteristics borrowing-constrained households have and whether borrowing constraints have an important influence on household consumption behavior using Japanese micro data from the 1994 "Public Opinion Survey on Household Savings and Consumption (POSSC). We identified borrowing-constrained households using three indicators, the data for some of which are unique to our data source. We obtained the following results: first, households that have complaints about the loan screening procedures of financial institutions and those whose non-housing wealth is less than two months' worth of income have a

${ }^{13}$ We also tried conducting a similar analysis using data from the 2000 POSSC and found that the results were not significantly different from the results using the 1994 POSSC. The reason why we used the 1994 POSSC is as follows: first, as we stated earlier, the POSSC has not asked the question about whether or not households are using credit cards since the 1995 survey. Second, the POSSC has asked only a question about the direction of change in a household's income (which is similar to the question about the change in a household's consumption in the 1994 POSSC) since the 1995 survey. Third, the POSSC has not asked the question about the direction of changes in a household's consumption and income and has asked only a question about the direction of change in a household's saving since 2001. 
higher amount of outstanding loans, especially "unspecific" loans, than all households. Second, households that are not using credit cards have a smaller amount of outstanding loans than other households except that they borrow more from their relatives and acquaintances. Thus, the characteristics of borrowing-constrained households differ greatly depending on which indicator we use, and whether or not households have complaints about the loan screening procedures of financial institutions and whether or not households' non-housing wealth is less than two months' worth of income appear to be far better indicators than whether or not households are using credit cards.

Third, we examined whether changes in the household's consumption differ significantly by whether or not it is borrowing-constrained and found that changes in the current income of households that are likely to be borrowing-constrained have a positive and significant impact on changes in their consumption in almost all cases, whereas changes in the current income of households that are unlikely to be borrowing-constrained do not have a significant impact on changes in their consumption in any case. These results suggest that borrowing constraints have an important influence on household consumption behavior and that the presence of borrowing constraints is one explanation for why the life cycle-permanent income hypothesis does not hold in the real world.

We turn finally to directions for further research. First, the data source we used in our analysis also collects information on changes in each household's saving so we would also like to examine whether changes in the household's current income have an impact on changes in its saving. Second, Kohara and Horioka $(1998,2001)$ point out that one of the most appropriate proxies for borrowing constraints is the household head's educational attainment, but the data source we use does not collect direct information thereon. We tried using indirect information on educational attainment in order to analyze the relationship between borrowing constraints and 
the household head's educational attainment, but we do not present the results here because almost all of the coefficients were not significantly different from zero. 


\section{REFERENCES}

Carroll, Christopher D. (2001), "Death to the Log-Linearized Consumption Euler Equation! And Very Poor Health to the Second-Order Approximation)," Advances in Macroeconomics 1 (1), 1003-1039.

Greene, William H. (2002), 'Econometric Analysis, Fifth Edition, Prentice Hall.

Hayashi, Fumio. (1985), “The Effect of Liquidity Constraints on Consumption: A Cross Sectional Analysis," Quarterly Journal of Economics 100, pp.183-206.

Hayashi, Fumio (1987), “Tests for Liquidity Constraints: A Critical Survey and Some New Observations," in Truman Bewley, ed., Advances in Econometrics, vol. II, Cambridge University Press, pp. 91-110.

Kohara, Miki, and Horioka, Charles Yuji (1998), "Kariire Seiyaku to Shouhi Koudou \{Borrowing Constraints and Consumption Behavior\}" in Y. Higuchi and M. Iwata, eds., Paneru Deta karamita Gendai Josei \{Contemporary Women as Seen from Panel Data\}, Toyo Keizai Shinpousha, Tokyo, pp. 225-258 (in Japanese).

Kohara, Miki, and Horioka, Charles Yuji (2001) "Do Borrowing Constraints Matter?" mimeo.

Jappelli, Tullio (1990), “Who Is Credit Constrained in the U.S. Economy?," Quarterly Journal of Economics 105, 220-234.

Jappelli, Tullio; Pischke, Jorn-Steffen; and Souleles, Nicholas S. (1998), “Testing for Liquidity Constraints in Euler Equations with Complementary Data Sources," Review of Economics and Statistics 80 (2), 251-262.

Kang, Sung Jin, and Sawada, Yasuyuki (2005), “A Credit Crunch and Household Welfare: The Case of the Korean Financial Crisis," mimeo.

Ludvigson, Sydney, and Paxson, Christina H. (2001), “Approximation Bias in Linearized Euler Equations," Review of Economics and Statistics 83 (2), 242-256. 
Maddala, G. S. (1983), Limited-Dependent and Qualitative Variables in Econometrics, Cambridge University Press.

Modigliani, Franco, and Brumberg, Richard E. (1954) "Utility Analysis and the Consumption Function: An Interpretation of Cross-Section data," in K. K. Kurihara, ed., Post Keynesian Economics, Rutgers University Press, New Brunswick, pp. 388-436.

Nawata, Kazumitsu (1995), "Estimation of Sample-Selection Models by the Maximum Likelihood Method," Mathematics and Computers in Simulation, 39, 299-303.

Ogawa, Kazuo (1990), "Cyclical Variations in Liquidity Constrained Consumers: Evidence from Macro Data in Japan," Journal of the Japanese and International Economies 4, 173-193.

Ogawa, Kazuo, and Horioka, Charles Yuji (1996), "Shouhi/Chochiku (Consumption/Saving)" in Kaizuka, K.; Kousai, Y.; and Nonaka, I., eds., Nihon Keizai Jiten (Encyclopedia on the Japanese Economy,) Nihon Keizai Shimbunsha, Tokyo, pp. 965-980 (in Japanese).

Runkle, David E. (1991), "Liquidity Constraints and the Permanent Income Hypothesis: Evidence from Panel Data," Journal of Monetary Economics 27, 73-98.

Sawada, Yasuyuki; Ii, Masako; and Nawata; Kazumitsu (1994), "Credit Crunch in Japan: An Augmented Euler Equation Approach by Using Type 5 Tobit Model,” mimeo.

Shintani, Mototsugu (1994), "Japanese Consumers and Liquidity Constraints: A Test based on Credit Information," Osaka Economic Paper. 44 (1), 41-56.

Wooldridge, Jeffrey M. (2002), "Econometric Analysis of Cross section and Panel Data," Massachusetts Institute of Technology Press.

Zeldes, Stephen. P. (1989), Consumption and Liquidity Constraints: An Empirical Investigation, Journal of Political Economy, 97 (2), 305-34. 


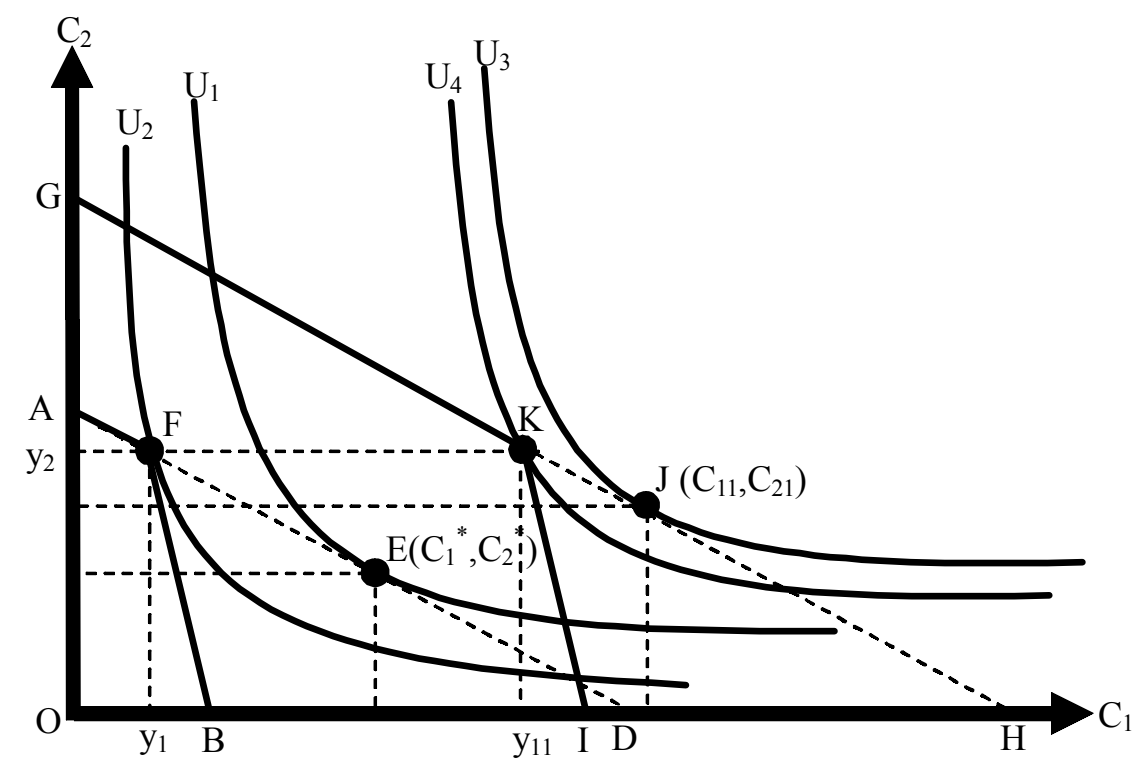

Figure 1. A Theoretical Analysis of the Impact of Borrowing Constraints on Consumption Behavior. 


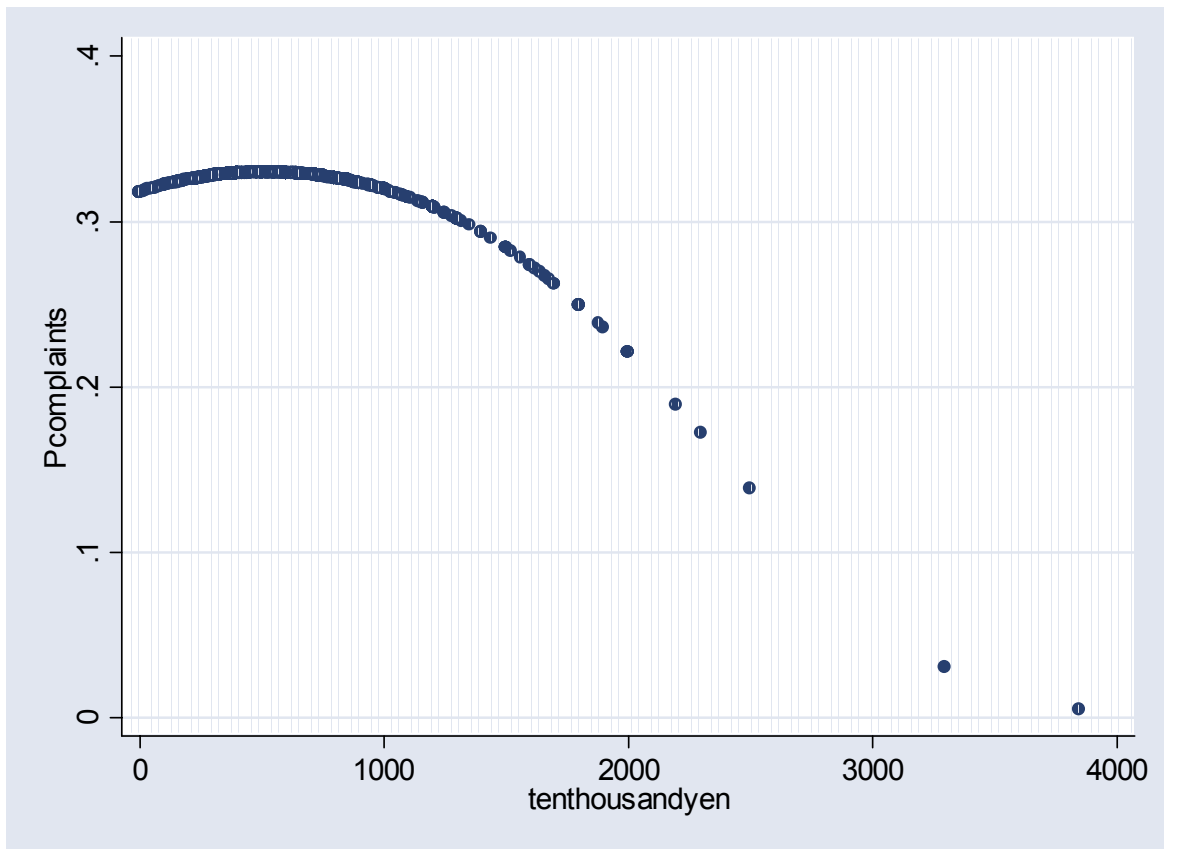

Figure 2-1. The Probability of Being Borrowing-Constrained using the First Indicator.

(Borrowing-constrained households are households that have complaints about the loan screening procedures of financial institutions.) 


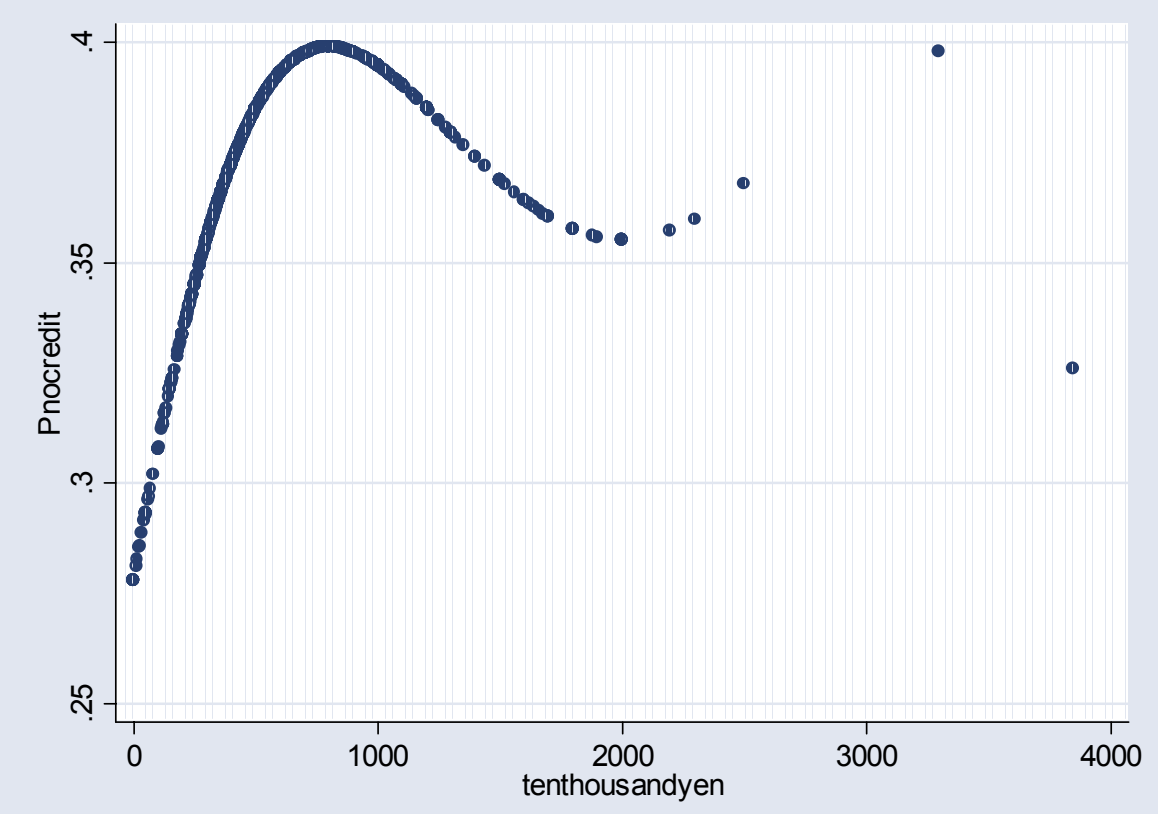

Figure 2-2. The Probability of Being Borrowing-Constrained using the Second Indicator.

(Borrowing-constrained households are households that are not using credit cards.) 
Table 1: Descriptive Statistics (Means and Standard Deviations)

\begin{tabular}{|c|c|c|c|c|}
\hline Variable & $\begin{array}{l}\text { All Households } \\
\text { (1777) }\end{array}$ & $\begin{array}{l}\text { (1) Households } \\
\text { that have } \\
\text { complaints about } \\
\text { the loan screening } \\
\text { procedures of } \\
\text { financial } \\
\text { institutions (493) }\end{array}$ & $\begin{array}{l}\text { (2) Households } \\
\text { that are not using } \\
\text { credit cards } \\
(1027)\end{array}$ & $\begin{array}{l}\text { (3) Households } \\
\text { whose non- } \\
\text { housing wealth is } \\
\text { 1; ess than two } \\
\text { months' worth of } \\
\text { income ( } 267)\end{array}$ \\
\hline Household head's age & $\begin{array}{r}49.59 \\
(12.22)\end{array}$ & $\begin{array}{r}46.75 \\
(10.73)\end{array}$ & $\begin{array}{r}51.80 \\
(12.37)\end{array}$ & $\begin{array}{r}45.97 \\
(11.34)\end{array}$ \\
\hline Family size & $\begin{array}{r}3.60 \\
(1.30)\end{array}$ & $\begin{array}{r}3.85 \\
(1.30)\end{array}$ & $\begin{array}{r}3.54 \\
(1.36)\end{array}$ & $\begin{array}{r}3.07 \\
(2.37)\end{array}$ \\
\hline $\begin{array}{l}\text { Income in the previous year } \\
\text { (millions of yen) }\end{array}$ & $\begin{array}{r}579.60 \\
(315.80)\end{array}$ & $\begin{array}{r}580.34 \\
(287.47)\end{array}$ & $\begin{array}{r}539.17 \\
(296.95)\end{array}$ & $\begin{array}{r}578.75 \\
(315.84)\end{array}$ \\
\hline Income in the year before last & $\begin{array}{r}5.796 \\
(3.173)\end{array}$ & $\begin{array}{r}5.844 \\
(2.826)\end{array}$ & $\begin{array}{r}5.401 \\
(2.849)\end{array}$ & $\begin{array}{r}5.682 \\
(3.131)\end{array}$ \\
\hline Financial assets & $\begin{array}{r}7.286 \\
(9.846)\end{array}$ & $\begin{array}{r}4.865 \\
(7.260)\end{array}$ & $\begin{array}{r}6.754 \\
(9.755)\end{array}$ & $\begin{array}{r}0.335 \\
(0.394)\end{array}$ \\
\hline New loans per year & $\begin{array}{r}0.332 \\
(2.450)\end{array}$ & $\begin{array}{r}0.538 \\
(3.140)\end{array}$ & $\begin{array}{r}0.310 \\
(2.403)\end{array}$ & $\begin{array}{r}0.695 \\
(4.135)\end{array}$ \\
\hline $\begin{array}{l}\text { Repayment of outstanding loans } \\
\text { per year }\end{array}$ & $\begin{array}{r}0.515 \\
(1.262)\end{array}$ & $\begin{array}{r}0.705 \\
(1.194)\end{array}$ & $\begin{array}{r}0.407 \\
(1.273)\end{array}$ & $\begin{array}{r}0.764 \\
(1.260)\end{array}$ \\
\hline Consumption expenditure & $\begin{array}{r}4.745 \\
(2.707)\end{array}$ & $\begin{array}{r}4.781 \\
(2.728)\end{array}$ & $\begin{array}{r}4.495 \\
(2.542)\end{array}$ & $\begin{array}{r}4.643 \\
(2.493)\end{array}$ \\
\hline Total outstanding loans & $\begin{array}{r}4.245 \\
(8.699)\end{array}$ & $\begin{array}{r}6.362 \\
(10.962)\end{array}$ & $\begin{array}{r}3.389 \\
(7.277)\end{array}$ & $\begin{array}{r}6.701 \\
(11.612)\end{array}$ \\
\hline $\begin{array}{l}\text { Borrowing from government } \\
\text { housing loan finance institutions }\end{array}$ & $\begin{array}{r}2.189 \\
(5.578)\end{array}$ & $\begin{array}{r}2.888 \\
(6.297)\end{array}$ & $\begin{array}{r}1.817 \\
(4.739)\end{array}$ & $\begin{array}{r}3.228 \\
(7.187)\end{array}$ \\
\hline $\begin{array}{l}\text { Borrowing from financial } \\
\text { institutions (banks, post offices, } \\
\text { etc. ) }\end{array}$ & $\begin{array}{r}1.515 \\
(5.676)\end{array}$ & $\begin{array}{r}2.802 \\
(8.161)\end{array}$ & $\begin{array}{r}1.103 \\
(4.307)\end{array}$ & $\begin{array}{r}2.590 \\
(8.520)\end{array}$ \\
\hline $\begin{array}{l}\text { Borrowing from sales } \\
\text { companies and credit card } \\
\text { companies }\end{array}$ & $\begin{array}{r}0.086 \\
(0.409)\end{array}$ & $\begin{array}{r}0.166 \\
(0.582)\end{array}$ & $\begin{array}{r}0.046 \\
(0.314)\end{array}$ & $\begin{array}{r}0.223 \\
(0.683)\end{array}$ \\
\hline $\begin{array}{l}\text { Borrowing from money lender } \\
\text { companies }\end{array}$ & $\begin{array}{r}0.006 \\
(0.104)\end{array}$ & $\begin{array}{r}0.018 \\
(0.195)\end{array}$ & $\begin{array}{r}0.003 \\
(0.081)\end{array}$ & $\begin{array}{r}0.010 \\
(0.102)\end{array}$ \\
\hline Borrowing from one's employer & $\begin{array}{r}0.359 \\
(2.221)\end{array}$ & $\begin{array}{r}0.408 \\
(1.942)\end{array}$ & $\begin{array}{r}0.295 \\
(2.229)\end{array}$ & $\begin{array}{r}0.512 \\
(2.287)\end{array}$ \\
\hline $\begin{array}{l}\text { Borrowing from relatives and } \\
\text { acquaintances }\end{array}$ & $\begin{array}{r}0.068 \\
(0.824)\end{array}$ & $\begin{array}{r}0.064 \\
(0.523)\end{array}$ & $\begin{array}{r}0.089 \\
(0.941)\end{array}$ & $\begin{array}{r}0.118 \\
(1.111)\end{array}$ \\
\hline Housing loans & $\begin{array}{r}3.779 \\
(8.401)\end{array}$ & $\begin{array}{r}5.530 \\
(10.444)\end{array}$ & $\begin{array}{r}3.053 \\
(7.088)\end{array}$ & $\begin{array}{r}5.858 \\
(11.360)\end{array}$ \\
\hline Unspecified loans & $\begin{array}{r}0.350 \\
(1.746)\end{array}$ & $\begin{array}{r}0.660 \\
(2.670)\end{array}$ & $\begin{array}{r}0.256 \\
(1.562)\end{array}$ & $\begin{array}{r}0.622 \\
(2.642)\end{array}$ \\
\hline
\end{tabular}




\begin{tabular}{|l|cccc|}
\hline The ratio of households that are & & & & \\
in debt & 44.51 & 60.24 & 36.51 & 62.17 \\
Homeownership ratio & 65.79 & 62.27 & 68.45 & 59.18 \\
Salaried household ratio & 59.09 & 59.92 & 53.65 & 62.17 \\
Unemployment ratio (those aged & & & & \\
under 60) & 0.96 & 0.41 & 1.36 & 0.37 \\
\hline
\end{tabular}

Source: The 1994 Public Opinion Survey on Household Savings and Consumption (in Japanese, Chochiku to Shouhi ni kansuru Yoron Chousa).

Note: Standard deviations are in parentheses. 
Table 2: Changes in consumption and income

\begin{tabular}{|l|rrr|rr|}
\hline (2-1) Full sample & Income & & & & \\
Consumption & Decreased & No change & Increased & & Total \\
\hline Decreased & & 81 & 84 & 252 \\
& & $(4.90)$ & $(4.56)$ & $(4.73)$ & $(14.18)$ \\
No change & 131 & 312 & 311 & 754 \\
& $(7.37)$ & $(17.56)$ & $(17.50)$ & $(42.43)$ \\
Increased & 132 & 250 & 389 & 771 \\
& $(7.43)$ & $(14.07)$ & $(21.89)$ & $(43.39)$ \\
\hline Total & 350 & 643 & 784 & 1,777 \\
& $(19.70)$ & $(36.18)$ & $(44.12)$ & $(100.00)$ \\
\hline
\end{tabular}

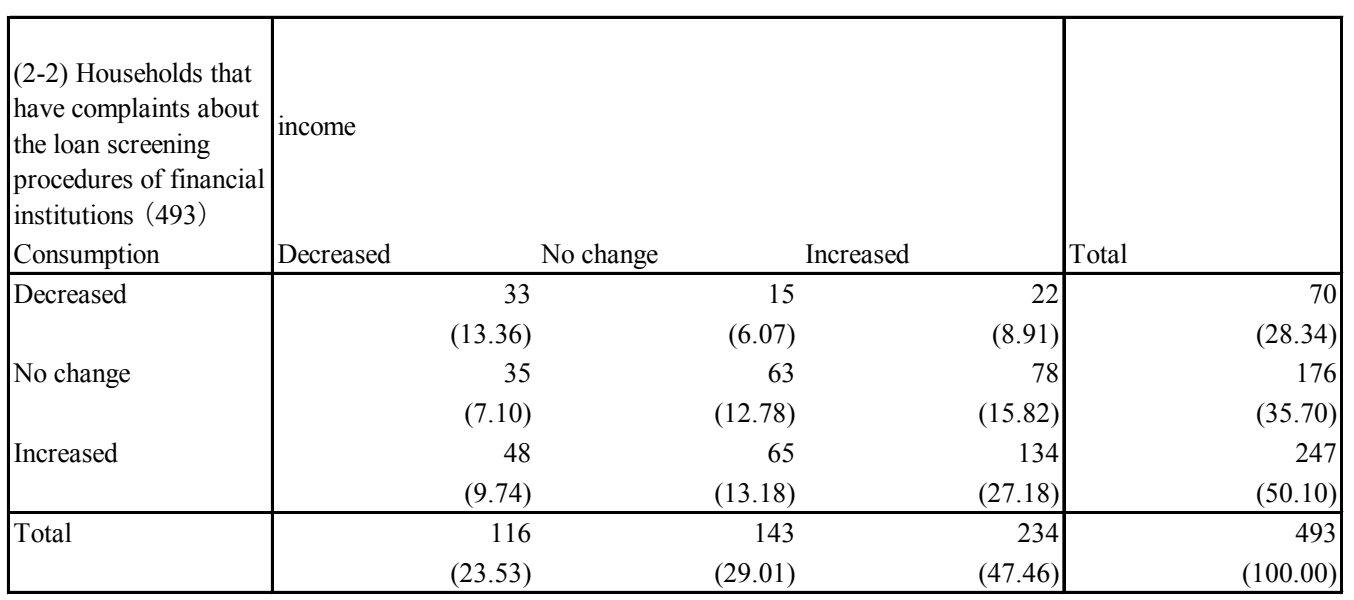

\begin{tabular}{|l|rrr|r|r|}
\hline $\begin{array}{l}\text { (2-3) Households that } \\
\text { are not using credit } \\
\text { cards }(1,027)\end{array}$ & & & & \\
Consumption & Income & & & & \\
& Decreased & No change & Increased & & Total \\
\hline Decreased & & 52 & 42 & 47 & 141 \\
& & $(5.06)$ & $(4.09)$ & $(4.58)$ & $(13.73)$ \\
No change & 79 & 210 & 181 & 470 \\
& $(7.69)$ & $(20.45)$ & $(17.62)$ & $(45.76)$ \\
Increased & 76 & 138 & 202 & 416 \\
& $(7.40)$ & $(13.44)$ & $(19.67)$ & $(40.51)$ \\
\hline Total & 207 & 390 & 430 & 1027 \\
& $(20.16)$ & $(37.97)$ & $(41.87)$ & $(100.00)$ \\
\hline
\end{tabular}

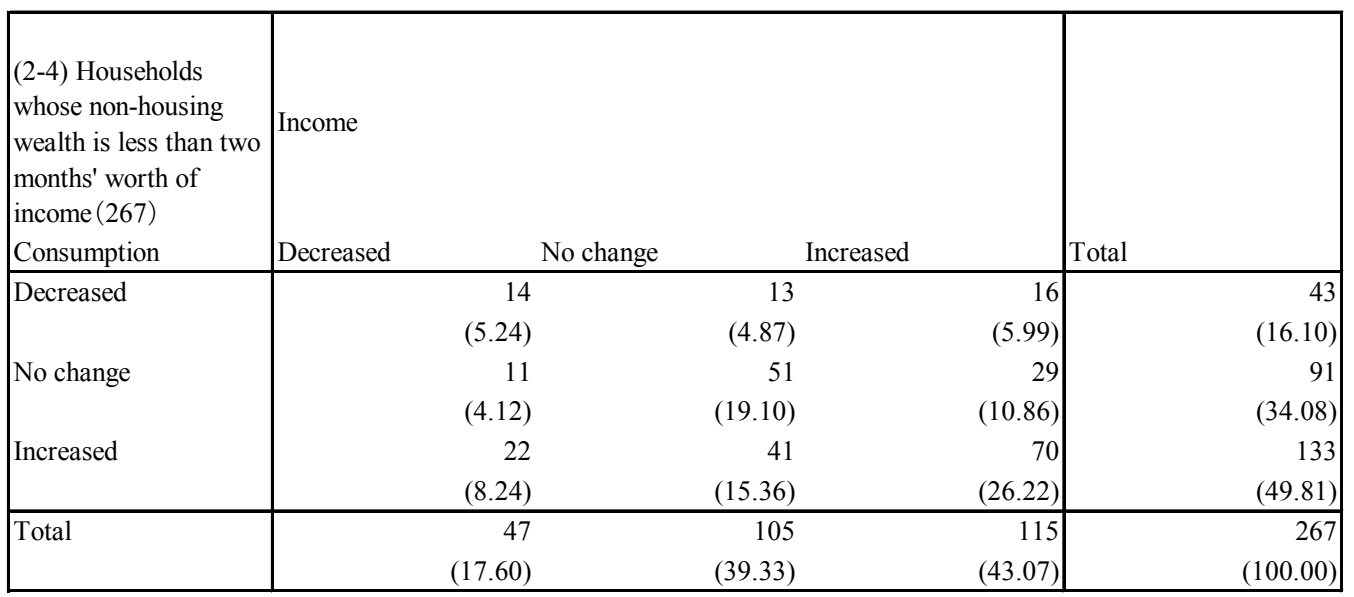


Table 3: What Characteristics Do Borrowing-Constrained Households Have?

(Estimated marginal effects from probit)

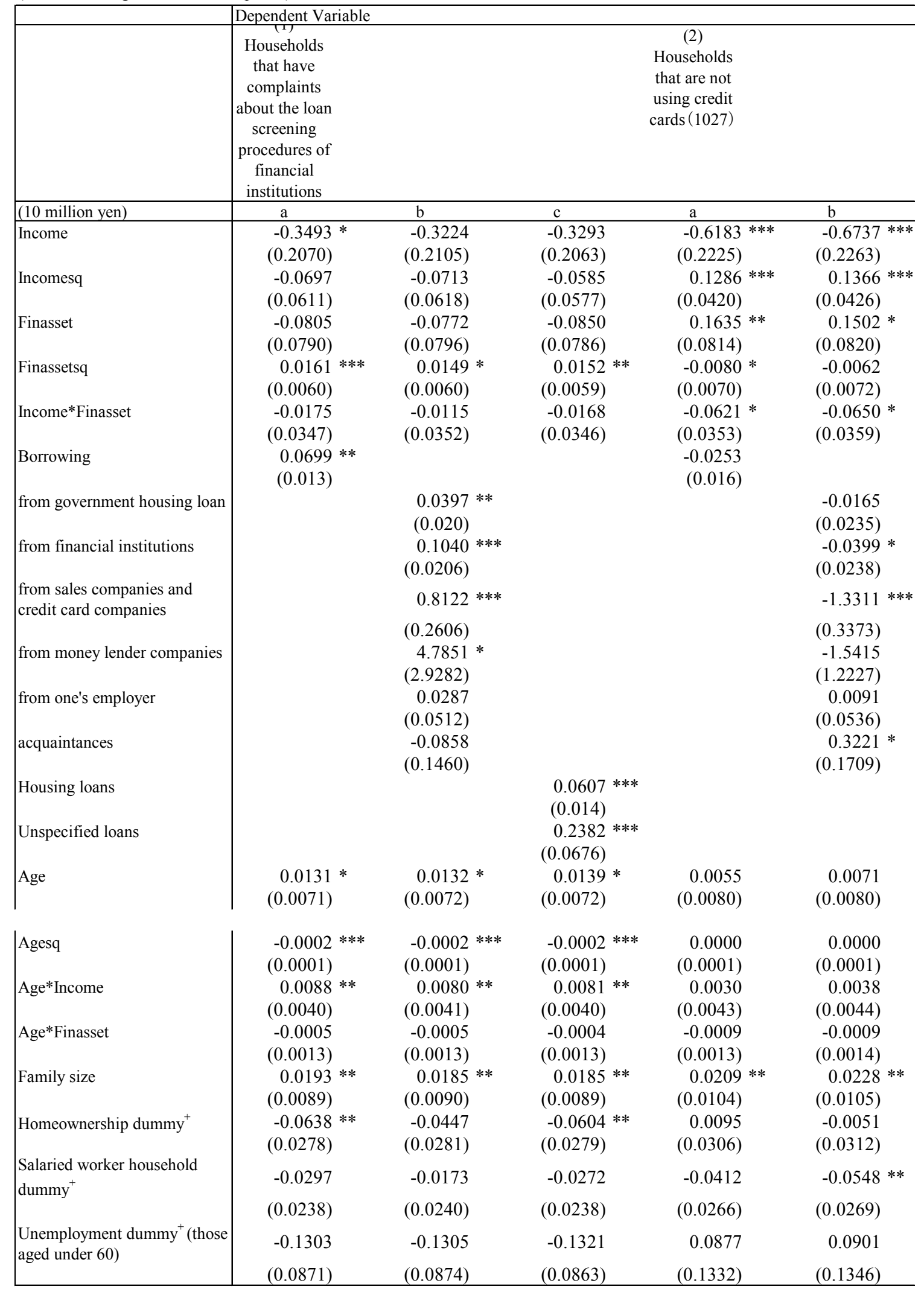




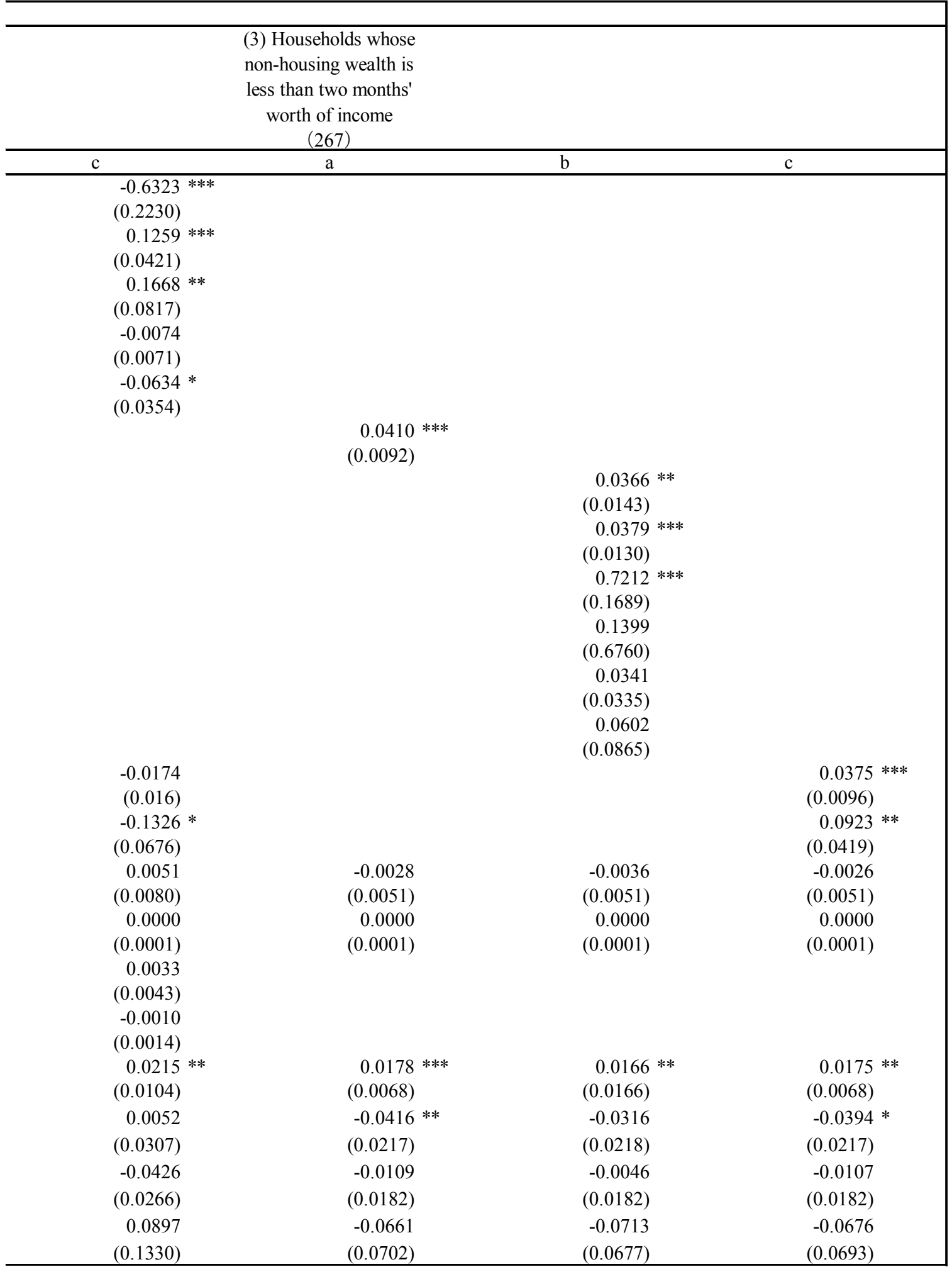


Notes:

*Significant at the $10 \%$ level, ${ }^{* *}$ significant at the $5 \%$ level, $* * *$ significant at the $1 \%$ level.

We use three indicators to define the dependent variable, which equals one for households that are likely to be borrowing-constrained and zero otherwise.

The estimated marginal effect can be derived from the height of the normal density multiplied by the coefficient of the explanatory variable.

$(+)$ The marginal effect is for a discrete change in the dummy variable from 0 to 1 . 
Table 4: Borrowing Constraints and Consumption Behavior $(\mathrm{N}=1777)$

(1) Whether or not households have complaints about the loan screening procedures of financial institutions

\begin{tabular}{|l|c|r|}
\hline Constrained & Change in consumption & Mean of variable \\
\hline Inincomedif & $0.229 *$ & -0.005 \\
& $(0.136)$ & 49.591 \\
Age & -0.019 & 2608.515 \\
Agesq & $(0.038)$ & \\
& 0.000 & \\
Constant & $(0.000)$ & \\
& $(0.454$ & \\
\hline Unconstrained & Change in consumption & \\
\hline Inincomedif & -0.0411 & \\
& $(0.0565)$ & \\
Age & -0.0113 & \\
& $(0.0205)$ & \\
Agesq & 0.0002 & \\
& $(0.0002)$ & \\
Constant & -0.1064 & \\
& $(0.5511)$ & \\
\hline mu1 & $1.9585 * * *$ & \\
mu2 & 11.5345 & \\
rho1 & 0.9969 & \\
& & \\
rho2 & $-0.9220 * * *$ & \\
& $(0.1199)$ & \\
\hline
\end{tabular}

Marginal effects in the case of contrained households -beta*xbar $\quad-1.1932$

mul-beta*xbar $\quad 0.7652$

\begin{tabular}{|l|lr|}
\hline & \multicolumn{3}{|l|}{ Estimated marginal effect } \\
\hline Decrease & $\mathrm{dP} 0 /$ dlnincome & -0.045 \\
No change & $\mathrm{dP} 1 /$ dlnincome & -0.023 \\
Increase & $\mathrm{dP} 2 /$ dlnincome & 0.068 \\
\hline
\end{tabular}

(2) Whether or not households are using credit cards

\begin{tabular}{|c|c|c|}
\hline Constrained & Change in consumption & Mean of variable \\
\hline lnincomedif & $\begin{array}{c}0.226 \text { ** } \\
(0.100)\end{array}$ & -0.005 \\
\hline Age & $\begin{array}{r}-0.009 \\
(0.027)\end{array}$ & 49.591 \\
\hline Agesq & $\begin{array}{r}0.000 \\
(0.000)\end{array}$ & 2608.515 \\
\hline Constant & $\begin{array}{l}1.398 * * \\
(0.686)\end{array}$ & \\
\hline Unconstrained & Change in consumption & \\
\hline Inincomedif & $\begin{array}{r}-0.1913 \\
(0.1438)\end{array}$ & \\
\hline Age & $\begin{array}{r}-0.0209 \\
(0.0411)\end{array}$ & \\
\hline Agesq & $\begin{array}{r}0.0002 \\
(0.0004)\end{array}$ & \\
\hline Constant & $\begin{array}{r}0.9164 \\
(1.2350) \\
\end{array}$ & \\
\hline mul & $\begin{array}{r}2.7832 \\
(7.4703)\end{array}$ & \\
\hline mu2 & $\begin{array}{r}20.5049 \\
(2576.1070)\end{array}$ & \\
\hline rhol & $0.9991 * * *$ & \\
\hline & $(0.0409)$ & \\
\hline rho2 & $\begin{array}{l}-0.1165 \\
(0.6981)\end{array}$ & \\
\hline
\end{tabular}

Marginal effects in the case of constrained households -beta*xbar $\quad-1.1486$ mu1-beta*xbar $\quad 1.6346$

\begin{tabular}{|l|lr|}
\hline & \multicolumn{2}{|l|}{ Estimated marginal effect } \\
\hline Decrease & $\mathrm{dP} 0 /$ dlnincome & -0.047 \\
No change & $\mathrm{dP} 1 /$ dlnincome & 0.023 \\
Increase & $\mathrm{dP} 2 /$ dlnincome & 0.024 \\
\hline
\end{tabular}


(3) Whether or not households' non-housing wealth is less than two months' worth of income

\begin{tabular}{|l|r|r|}
\hline Constrained & Change in consumption & Mean of variable \\
\hline Inincomedif & -0.163 & -0.005 \\
& $(0.218)$ & \\
Age & 0.000 & 49.591 \\
& $(0.069)$ & 2608.515 \\
Constant & 0.000 & \\
& $(0.001)$ & \\
\hline Unconstrained & 0.496 & \\
\hline lnincomedif & $(1.696)$ & \\
& 0.0920 & \\
Age & $(0.0995)$ & \\
& 0.0003 & \\
Agesq & $(0.0256)$ & \\
Constant & $(0.000003)$ & \\
& 0.4967 & \\
mu1 & $(0.9107)$ & \\
& 22.7334 & \\
mu2 & $(208046.9000)$ & \\
& 9.2475 & \\
rho1 & $(788.7313)$ & \\
& 0.0654 & \\
rho2 & -0.2535 & \\
& $(0.7860)$ & \\
\hline
\end{tabular}

